\title{
XLIX. On the occurrence of shells and corals in a conglomerate bed, adherent to the face of the trap rocks of the malvern hills, and full of rounded and angular fragments of those rocks
}

John Phillips Esq. F.R.S.

To cite this article: John Phillips Esq. F.R.S. (1842) XLIX. On the occurrence of shells and corals in a conglomerate bed, adherent to the face of the trap rocks of the malvern hills, and full of rounded and angular fragments of those rocks, Philosophical Magazine Series 3, 21:138, 288-293, DOI: $10.1080 / 14786444208621548$

To link to this article: http://dx.doi.org/10.1080/14786444208621548

曲 Published online: 01 Jun 2009.

Submit your article to this journal ¿

Џll Article views: 2

Q View related articles $\longleftarrow$ 
XLIX. On the Occurrence of Shells and Corals in a Conglomerate Bed, adherent to the face of the Trap Rocks of the Malvern Hills, and full of rounded and angular fragments of those rocks. By Joнn PhIllips, Esq., F.R.S., \&c.

THE researches of Sir $H$. T. De la Beche during the autumn 1 of 184.1 into the nature, antiquity and organic contents of the trappæan ash-beds of Nortl Pembroke, coupled with other parallel inquiries, have excited in the minds of those persons who are attached to the Ordnance Geological Survey a lively interest in the study of the relations between trap rocks and the strata amongst which they appear. A very common result of this study in South Wales is a conviction of the rarity of irruptive trap and the frequency of interstratified (and, in ordinary language, contemporaneous) beds of plutonic rocks and felspatho-hornblendic sediments, which are not always clearly distinguished from the fused rocks. On these points in the same or neighbouring districts, Professor Sedgwick and Mr. Murchison deliver nearly the same judgment.

The great obligations which geology owes to Mr. Leonard Horner and to Mr. Murchison for their descriptions of the fused and sedimentary rocks in this chain, and of the grand movements in the crust of the earth, of which it is a noble monument, are universally admitted, but demand a glad acknowledgement from one who, following in their steps and profiting by their experience, desires to join to theirs the additional information which he may be so fortunate as to gather.

After finishing the colouring of a great part of the Ordnance map of this district, I turned to examine with care and interest the great problem which the Malvern hills present, viz. the determination of the circumstances under which the plutonic rocks were elevated. For this purpose the appearance of the fused and sedimentary rocks in every part of the Malvern chain and the surrounding country has been considered, separately and in combination; and the general result is, that the elevation of these hills is a part of that grand series of associated movements, which the Director and other members of the Geological Survey have been tracing between St. Bride's Bay and the Severn, between the Teivy and the Bristol Channel.

Viewed in this association, the geological epoch when the great movement of the Malvern rocks occurred, becomes determinable, and has in fact been determined by the eminent geologists already named. No one can witness the many 
anticlinal and synclinal curvatures which on the western flank of the Malverns affect equally the Silurian and old red formations, and then survey the comparatively horizontal and unmoved strata of new red marls and sandstones, which on the east and south touch indiscriminately the sienites, Caradoc sandstones, Wenlock limestone, and old red sandstone, without being satisfied that the great upward movement of the Malvern rocks happened in the interval between the old and the new red sandstones.

But in what state were these plutonic masses raised? as fused and liquid matter, or solidified rock? To determine this question, the observed positions of the strata which adjoin the trap range are important, but their condition and contents are still more essential. My first expectation, on looking generally at the narrow continuous range of the Malverns, was, that here might be found an example of a gigantic sinuous mass, emitted in a liquid state along a portion of that great irregular fracture which is the western boundary of the new red sandstone, from the Severn to the Dee. The complicated nature of the trap, its innumerable vein-like segregations, its included gneissic beds, gave an additional interest to the examination of the appearances at and near the junction of the trap with the exterior stratified masses.

In aid of this inquiry I fortunately discovered two remarkable localities where Silurian strata of determinate age were in contact with the trap masses; one exposed in the deep cutting at the Wych, the other on the depressed summit of drainage between the Hereford beacon and Swinyard hill. Besides these are several examples of the sedimentary aggregates of the lower Silurian strata in juxtaposition or actual contact with the trap rocks of the high Malvern ridge; with a detached series of low insulated ridges and bosses of trap on the western side near the southern extremity of the chain; and with some low mounds described by Mr. Murchison at the northern extremity.

The appearances connected with the low points at the northern end, and with a part of the ridge near the southern extremity, have been considered to indicate metamorphism in stratified rocks by heat*; and the phænomena associated with the detached bosses and hillocks on the western side of the chain, may be believed to indicate irruption of trap amongst the lowest of the Silurian strata ; but generally along the chain itself, and especially in all the northern parts of it, there appears no evidence that the adjacent exterior strata have been invaded by liquid irruptive rock.

* Murchison's Silurian System, p. 417 et seq.

Phil. Mag. S.3. Vol. 21. No. 138. Oct. 184.2. 
In the deep cutting at the Wych, sandstones and shales of the Caradoc formation are placed in a singular manner between masses of trap, but are entirely unchanged in aspect, and retain the usual organic remains. On the summit ridge near Swinyard hill, the upper beds of the Caradoc series, with the usual Jimestone bands and shales of that part of the Silurian strata, rest against solid felspathic trap on the south side and cover it as with a saddle. The corals and shells here gathered were in their usual state, and the strata appear unaltered.

Contrasting these cases with others in the midst of the Malvern hills, where stratified rocks are irregularly mixed with the fused rocks, and have the character of gneiss, and with others on the western flanks where dykes and bosses of trap appear amongst peculiar sandstones and black shales, it appeared probable that some parts at least of the Malvern ridge were of higher antiquity than any of the exterior strata ; that amongst the lowest of these strata, local and limited irruptions of $a$ different sort of trap had occurred; but that the greater part of the Silurian strata visible in the northern parts of the hills had been subject to no peculiar heat emanating from the Malvern ridge.

In this condition of the argument Mr. Murchison and Count Keyserling passed through Malvern and inspected the section of the $W_{y c h}$, as well as the north end of the Malverns, and Professor Sedgwick accompanied me on a leisurely survey of this and other points further south. On the day (August 1) while I was enjoying the advantage of his experience in examining the facts thus briefly adverted to, a discovery was made which threw a new and concentrated light on the phænomena we were discussing.

My sister, knowing the interest I felt in tracing out the history of the stratification visible in these trap hills, sought diligently for organic remains in the midst of and on the western flanks of the sienitic masses of the North hill and Sugar-loaf hill. In this most unpromising search she was entirely successful, and collected from the midst of heaps of fallen stones, which seemed to be all trap, several masses richly charged with organic remains, and full of felspar, quartz, and horn, blende, in grains and large lumps. On careful examination, it was seen that those lumps were fragments, generally rolled to pebbles, and distributed with reference to one another and to the shells, just as quartz pebbles and chips are in a common conglomerate. It was, in fact, certainly and evidently a conglomerate full of Silurian shells, and pebbles and fragments of the sienitic, felspatho-quartzose and other rockmasses of the Malvern hills. 
The next thing to determine was the position of this conglomerate in relation to the ridge of sienitic rocks amongst the detritus of which its fragments lay. This was difficult.

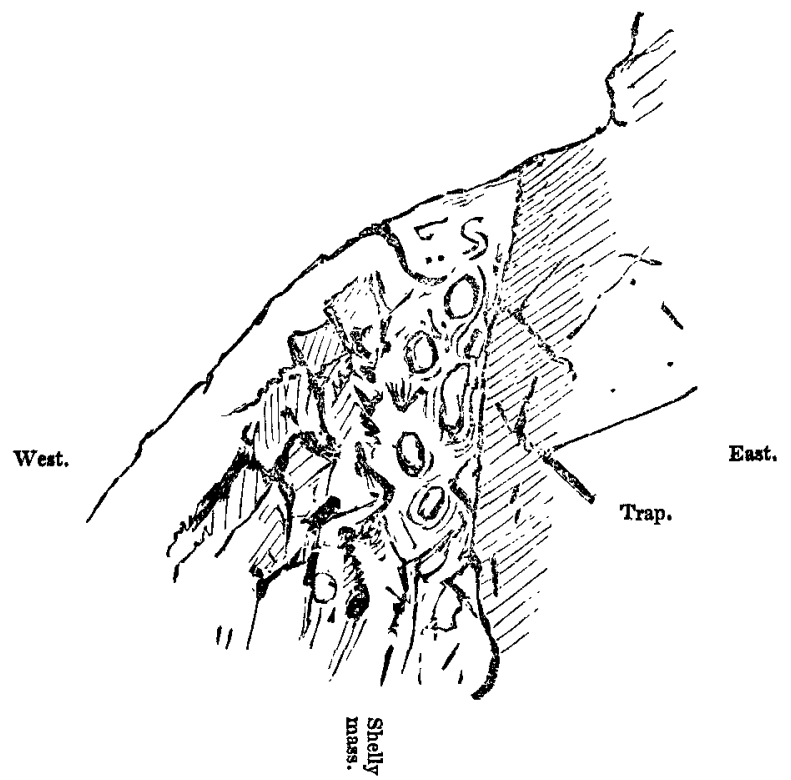

The abundance of detritus on all the slopes is so great as to conceal for the most part the junction of the stratified and unstratified rocks. The loose shelly pieces we found abundantly for fully one-third of a mile along the mountain side, and at length the conglomerate rock itself was plainly seen adhering to the extreme western nearly vertical face of the trap mass, west of the Worcestershire beacon, in a situation contiguous to a large excavation of the lower Caradoc sandstone.

These facts ascertained, I waited for the arrival of Sir H. T. De la Beche at Malvern, to have the shelly bed thoroughly explored, and its contact with the trap rocks carefully traced. We found the surface of the trap nearly vertical, but undulating and irregular, and its strike nearly north and south; the rock is here hornblendic, dark green or purplish in colour, and, as usual in all these hills, it is within short distances mixed and variegated with more felspathic portions, felspathoquartzose veins, \&c. Closely adhering to it was usually a softish laminated clay; bedded in the clay, or touching the trap rock, were multitudes of rolled pebbles and angular chips and fragments of stone, accumulated in an irregular bed above 


\section{On Shells and Corals in a Conglomerate at Malvern.}

a foot or only a few inches in thickness against the trap. In the intervals of these pebbles were partial admixtures of argillaceous shale, abundance of shells, and smaller chips and fragments of stone, more or less stained brown, in the same manner as commonly happens in shelly cavities in other conglomerates and sandstones far removed from the trap. Exterior to this very pebbly mass, the shells were equally numerous, but the rock fragments amongst which they lay were generally angular, appearing just as if they had fallen from a cliff upon a pebbly beach, and received into their interstices abundance of shells and sand drifted by the water.

The degree of firmness of the shelly masses thus examined in situ, is less on an average than that of the loose pieces on the hill slopes which were first observed; these latter being the hardest portions which best withstood destroying agencies.

The shells, corals and encrinites, are commonly represented by casts and moulds, but a few specimens have occurred of Turbinolopsis, with the calcareous substance entirely preserved.

The pebbles and fragments of stone mixed with the shells are of the same nature as the rocks immediately adjacent and composing the neighbouring hills; that is to say, characteristic compounds and segregations of hornblende, felspar, quartz, and mica, in great variety. The whole mass is stained by ferruginous admixtures, and at a small distance looks like some of the dark trap of the hills with which it is in contact. What may be its degree of induration at a considerable depth is unknown, the situation allowing only of an exploration to the depth of a few feet.

The just inference from the occurrence of the shelly conglomerate thus briefly described, appears to be that the sienitic and other associated rocks of the northern portion of the Malvern hills were accumulated and indurated previous to the aggregation of the lower portions of the Caradoc sandstone series; and that they were, with the whole Silurian series, raised in a solid state.

In harmony with this conclusion, is the abundance of fragments and disintegrated grains of the Malvern rocks in other conglomerates (not shelly) of the Caradoc series, about the north end of the chain, examined by Sir H. T. De la Beche and myself. Even in Ankerdine hill, eight miles north of Malvern, fragments of the sienitic rocks were observed in the Caradoc sandstone by Capt. James, R.E., and myself; and the conglomerate of May hill yielded similar results to Sir H. T. De la Beche.

Observations of this nature, combined with accurate sur- 
veys of the great lines of subterranean movement, may hereafter enlarge the limited view now presented of a part of the Malvern hills, into a general contemplation of the agency of heat during the Palæozoic periods in the great physical region between the vale of the Severn and the coasts of Wales. But to state such a speculation without the data which have been collected for its illustration, would be useless or injurious, and the constitution of even the Malvern chain itself is sufficiently varied in its different parts, to induce a long pause before the apparently proved high antiquity of the northern sienites should be implicitly extended even to the southern portion of the same chain.

Malvern, Sept. 19, 1842.

L. On the Dispersion of the Optic Axes, and of the Axes of Elasticity, in Biaxal Crystals. By James MacCullagh, LL.D., M.R.I.A., Fellow of Trinity College, and Professor of Mathematics in the University of Dublin*.

I the last Number of the Philosophical Magazine (p. 228), there appeared an extract from the Proceedings of the Royal Irish Academy, containing a notice of a memoir which $I$ had the honour of reading to that body on the 24th of May, 184:1; and in the concluding paragraph of the notice a brief allusion is made to a "mathematical hypothesis" by which I had connected the laws of dispersion and those of the elliptic polarization of rock-crystal with the other laws that were there announced. My present object is to indicate the development of that hypothesis, with reference more particularly to the subject of dispersion in crystals, and to communicate a very simple result which I have lately had occasion to obtain from it. The result is remarkable as embracing and explaining a class of intricate phænomena which hitherto have not been connected with any theory, or rather have stood in opposition to all theories; I mean the phænomena of the dispersion of the optic axes, and of the axes of elasticity (as they are called) in biaxal crystals.

The name of axes of elasticity was given by Fresnel to three rectangular directions, which, according to his theory, exist in every crystallized medium, and which are distinguished by the property, that if a particle of the medium be slightly displaced in the direction of any one of them, the elastic force thereby called into play will act precisely in the line of the displace-

* Communicated by the Author. 